\title{
Profile of adverse events in toxoplasmosis drug therapy: a review
}

\author{
Perfil de eventos adversos na terapia medicamentosa da toxoplasmose: uma revisão \\ Perfil de acontecimientos adversos en la drogoterapia de toxoplasmosis: una revisión
}

Received: 10/02/2021 | Reviewed: 10/10/2021 | Accept: 10/18/2021| Published: 10/20/2021

\author{
Karlla Mayara Nunes de Sousa \\ ORCID: https://orcid.org/0000-0002-5508-8295 \\ University of Pernambuco, Brazil \\ E-mail: karllamnsousa@hmail.com \\ Amanda Carla Corrêa Viana \\ ORCID: https://orcid.org/0000-0002-4442-7140 \\ University of Pernambuco, Brazil \\ E-mail: amandacarlacorreaviana@gmail.com \\ Silvana de Fátima Ferreira da Silva Caires \\ ORCID: https://orcid.org/0000-0003-4421-6228 \\ University of Pernambuco, Brazil \\ E-mail: silvana.ferreira@upe.br \\ Raquel Pedrosa Bezerra \\ ORCID: https://orcid.org/0000-0002-1801-2945 \\ Rural Federal University of Pernambuco, Brazil \\ E-mail: rpbezerra@gmail.com \\ Edmilson Mariano de Sousa Júnior \\ ORCID: https://orcid.org/0000-0003-2864-8960 \\ Federal University of Pernambuco, Brazil \\ E-mail: edmilson.junior@ufpe.br \\ Daniela de Araújo Viana Marques \\ ORCID: https://orcid.org/0000-0002-2380-7910 \\ University of Pernambuco, Brazil \\ E-mail: daniela.viana@upe.br
}

\begin{abstract}
This study aims to analyze the profile of adverse events (AEs) of drugs for the treatment of Toxoplasmosis. This is a review carried out through a bibliographic search in the electronic databases PubMed, SciELO, Cochrane Digital Library and LILACS. The keywords "Toxoplasmosis" AND "Drug Therapy" AND "Drug-Related Side Effects and Adverse Reactions" were used. The selection was performed by two independent reviewers and the articles were included considering the presence of retrospective studies and case reports published in the literature in Portuguese and English and without time restrictions. In total, 40 articles were found, of which 14 met the inclusion criteria. Cases of cerebral, ocular, gestational and congenital Toxoplasmosis were identified. Among these, we observed a total of 85 patients with reports of AEs due to the use of Pyrimethamine, Sulfadiazine, Spiramycin, Clindamycin, Atovaquone, Trimethoprim and Sulfamethoxazole and Sulfadoxine. Clinical reactions were in the form of skin rash (57.1\%), hematological alterations (28.5\%), Lyell syndromes (7.1\%), Stevens-Johnson (21.4\%) and DRESS (21.4\%). The prevalence of AEs related to hematological alterations was seen mainly in treatments based on Pyrimethamine + Sulfadiazine, Trimethoprim and Sulfamethoxazole; on the other hand, those associated with severe syndromes are often related to the use of Pyrimethamine + Sulfadiazine. It is important to establish a standard protocol for drug therapy for Toxoplasmosis, which does not yet exist. In addition, the need to monitor patients after drug administration is highlighted, given the possibility of the occurrence of adverse events that can represent a threat to life.
\end{abstract}

Keywords: Drug-related side effects; Adverse reactions; Drug therapy; Toxoplasmosis; Pyrimethamine.

\section{Resumo}

Este estudo tem como objetivo analisar o perfil de eventos adversos (EAs) dos medicamentos de tratamento da Toxoplasmose. Trata-se de uma revisão realizada por meio de busca bibliográfica nas bases eletrônicas de dados PubMed, SciELO, Cochrane Digital Library e LILACS. Utilizou-se as palavras-chaves "Toxoplasmosis" AND "Drug Therapy" AND "Drug-Related Side Effects and Adverse Reactions". A seleção foi realizada por dois revisores independentes e os artigos foram incluídos considerando a presença de estudos retrospectivos e relatos de caso publicados na literatura nos idiomas Português e Inglês e sem restrição de tempo. No total, foram encontrados 40 artigos, dos quais 14 preencheram os critérios de inclusão. Foram identificados casos de Toxoplasmose cerebral, ocular, gestacional e congênita. Dentre esses, observou-se um total de 85 pacientes com relatos de EAs pelo uso de 
Pirimetamina, Sulfadiazina, Espiramicina, Clindamicina, Atovaquona, Trimetoprima e Sulfametoxazol e Sulfadoxina. As reações clínicas se apresentaram sob as formas de rash cutâneo (57,1\%), alterações hematológicas $(28,5 \%)$, Síndromes de Lyell (7,1\%), Stevens-Johnson (21,4\%) e DRESS $(21,4 \%)$. A prevalência de EAs relacionados à alterações hematológica foi vista, principalmente, nos tratamentos à base de Pirimetamina + Sulfadiazina, Trimetoprima e Sulfametoxazol; já as dermatológicas associadas com síndromes graves estão frequentemente relacionados com uso de Pirimetamina + Sulfadiazina. Verifica-se a importância do estabelecimento de um protocolo padrão para a terapia medicamentosa da Toxoplasmose, ainda não existente. Além disso, destaca-se a necessidade do monitoramento dos pacientes após a administração das drogas, visto a possibilidade da ocorrência de eventos adversos que podem se configurar como uma ameaça à vida.

Palavras-chave: Toxoplasmose; Tratamento farmacológico; Efeitos colaterais e reações adversas relacionado as a medicamentos.

\section{Resumen}

Este estudio tiene como objetivo analizar el perfil de eventos adversos (EA) de los fármacos para el tratamiento de la toxoplasmosis. Se trata de una revisión realizada a través de una búsqueda bibliográfica en las bases de datos electrónicas PubMed, SciELO, Cochrane Digital Library y LILACS. Se utilizaron las palabras clave "Toxoplasmosis" Y "Terapia con medicamentos" Y "Efectos secundarios y reacciones adversas relacionados con los medicamentos". La selección fue realizada por dos revisores independientes y los artículos fueron incluidos considerando la presencia de estudios retrospectivos e informes de casos publicados en la literatura en portugués e inglés y sin restricciones de tiempo. En total, se encontraron 40 artículos, de los cuales 14 cumplieron los criterios de inclusión. Se identificaron casos de toxoplasmosis cerebral, ocular, gestacional y congénita. Entre estos, observamos un total de 85 pacientes con informes de EA debido al uso de pirimetamina, sulfadiazina, espiramicina, clindamicina, atovacuona, trimetoprim y sulfametoxazol y sulfadoxina. Las reacciones clínicas fueron en forma de erupción cutánea $(57,1 \%)$, alteraciones hematológicas $(28,5 \%)$, síndromes de Lyell $(7,1 \%)$, Stevens-Johnson $(21,4 \%)$ y DRESS $(21,4 \%)$. La prevalencia de EA relacionados con alteraciones hematológicas se observó principalmente en tratamientos basados en Pirimetamina + Sulfadiazina, Trimetoprim y Sulfametoxazol; por otro lado, los asociados con síndromes graves suelen estar relacionados con el uso de pirimetamina + sulfadiazina. Es importante establecer un protocolo estándar para la terapia con medicamentos para la toxoplasmosis, que aún no existe. Además, se resalta la necesidad de monitorear a los pacientes luego de la administración del fármaco, dada la posibilidad de que ocurran eventos adversos que pueden representar una amenaza para la vida.

Palabras clave: Toxoplasmosis; Tratamiento farmacológico; Efectos colaterales y reacciones adversas relacionadas con los fármacos.

\section{Introduction}

Toxoplasmosis is caused by Toxoplasma gondii protozoan (T. gondii), a mandatory intracellular parasite belonging to the phylum Apicomplexa. It is widespread globally and is capable of infecting a wide range of hosts, with felids as the definitive hosts, and humans, birds, and other mammals as intermediate hosts. About a third of the world's population has a chronic infection, among which seroprevalence varies by country. In Brazil, for example, seroprevalence is higher than $60 \%$ (Alday \& Doggett, 2017; Dubey et al., 2012).

Most human T. gondii infections occur through ingestion of sporulated oocysts, which are eliminated in feline feces and contaminate soil, water, and food, or through bradyzoites found in the form of tissue cysts in raw or undercooked meat. Tachyzoites are another infectious form. They are present in biological fluids and found during acute infection; they are also responsible for transplacental transmission (Paradynski et al., 2019).

Generally, acute T. gondii infection in immunocompetent individuals is followed by latent infection associated with the formation of cysts in various organs, mainly in the cardiac and skeletal muscles, cerebral parenchyma, and retina. However, latent infection can be reactivated in immunocompromised patients, in whom bradyzoites, a form of latent cyst, are rapidly reversed into replicating tachyzoites, causing severe diseases such as toxoplasmic encephalitis and serious eye injuries (Dunay et al., 2018). Regarding congenital transmission, the consequences of infection can lead not only to outcomes that will accompany the child through life, such as neurological and ocular sequelae, but also cause fetal and perinatal death, which is a public health problem (Serrano, 2016).

There is no treatment to eradicate toxoplasmosis, as the available drugs have no effect on bradyzoite cysts that are 
deposited in the host and can be reactivated later (Bernardo et al., 2015). The only available treatment is for tachyzoites. However, there are considerable variations in drugs, dosage, and treatment duration, and none is considered the gold standard (Wei et al., 2015). In order to suppress tachyzoite replication, most drugs target the inhibition of the enzymes dihydrofolate reductase (DHFR) and dihydropteroate synthase (DHPS) to block the synthesis of folic acid. Thus, it appears that the drugs used in treatments have high rates of cytotoxicity, side effects, and adverse reactions, which often lead to the abandonment of therapy (Alday \& Doggett, 2017; Deng et al., 2019).

Thus, the objective of this review is to provide comprehensive information about the profile of adverse events (AEs) caused by the therapy available for the treatment of toxoplasmosis. This entails identifying the drugs and dosages used, and the main clinical reactions.

\section{Methodology}

This is a qualitative study. Our research was limited to articles written in Portuguese and English, without time restrictions. A bibliographic search of the electronic databases PubMed, SciELO, Cochrane Digital Library, and LILACS was carried out from June to July 2020. The keywords were chosen based on the Health Sciences Descriptors (DeCS) combined with the Boolean operator (AND): toxoplasmosis AND drug therapy AND drug-related side effects and adverse reactions. And the flow diagram that describes the flow of information in the different phases of the review referring to the results of the selection of articles was prepared following the PRISMA parameters.

\subsection{Inclusion and exclusion criteria}

Original, retrospective, and case reports were included, with the following inclusion criteria: 1) investigation of AEs related to the drugs used in the treatment of toxoplasmosis and 2) studies that provide detailed information about the prevalence of adverse reactions caused by drugs used in toxoplasmosis therapy. The exclusion criteria were: 1) reviews were removed from the literature; 2) studies developed in vitro and in animal models; 3) publications in languages other than Portuguese and English; and 4) lack of adequate data and irrelevant studies regarding not detailed approach to specific adverse events caused by the medication and number of patients.

\subsection{Study selection and data extraction}

After selecting articles that met the inclusion criteria, two independent reviewers carefully examined their titles, abstracts and full articles for eligibility. Subsequently, reviewer divergences were discussed and resolved by consensus. The extracted information included: year of study and author; adverse events; type of manifestation of toxoplasmosis and the treatment drug.

\section{Results and Discussion}

The bibliographical research resulted in the selection of 40 articles. Of these, 23 articles were excluded after the reviewers had read the titles and abstracts. Of the 17 articles that were selected for full reading, only 14 articles met all eligibility criteria and were included in this review (Figure 1). 
Figure 1 Search and selection flowchart of studies carried out following the PRISMA.
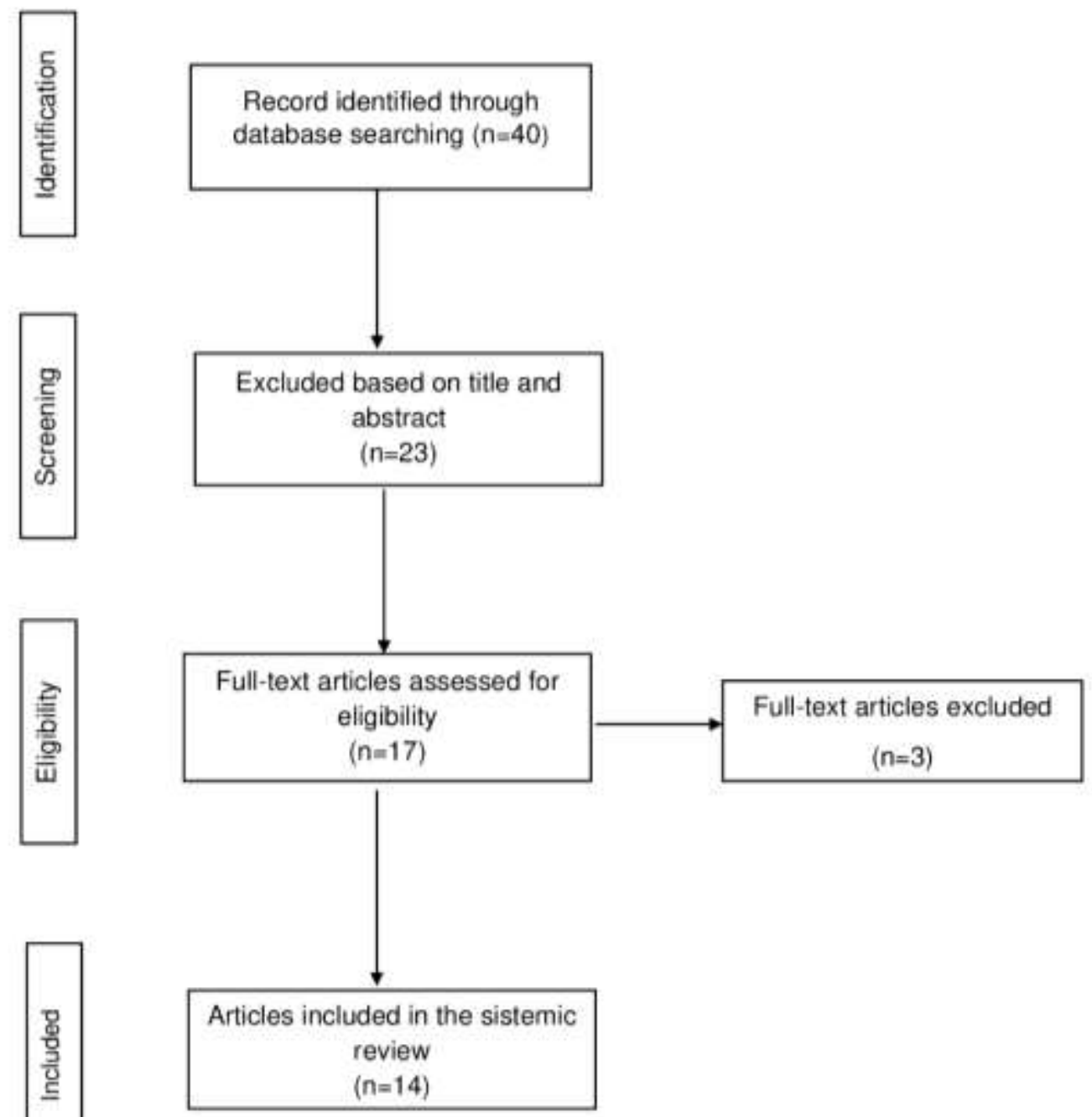

Source: Adapted from MacKenzie JE et al. (2021).

Drugs such as pyrimethamine, sulfadiazine, clindamycin, azithromycin, trimethoprim, sulfamethoxazole (cotrimoxazole), dapsone, spiramicin, and atovaquone can be used to treat toxoplasmosis. However, none of these is satisfactory regarding effectiveness against all forms of $T$. gondii and safety due to the frequent occurrence of adverse events, as demonstrated in $85 \%$ of patients treated for ophthalmic toxoplasmosis (Guaraldo et al., 2018; Iaccheri et al., 2008).

Gestational, congenital, cerebral, and ocular toxoplasmosis were observed in case reports and studies published between 1991 and 2018, in which 85 patients were included (Table 1). Eight studies used drugs such as trimethoprim combined with sulfamethoxazole, or a combination of sulfadiazine and pyrimethamine, and reported the concomitant administration of folinic acid, since these drugs inhibit the synthesis of folic acid and are mainly related to AEs associated with bone marrow suppression. However, in four (28.5\%) of the 14 studies that used folinic acid, together with the adopted therapy, the patients presented with hematological changes. ${ }^{[1,12,14]}$. 
Table 1. Characteristics of studies on adverse reactions caused by drugs used in toxoplasmosis therapy.

\begin{tabular}{|c|c|c|c|c|c|}
\hline & Author & Clinical manifestation & $\begin{array}{l}\text { No. of } \\
\text { Patients }\end{array}$ & Treatment & Adverse Event \\
\hline 1. & $\begin{array}{l}\text { Canessa et al. } \\
\text { (1992) }\end{array}$ & Cerebral & 1 & $\begin{array}{c}\text { TS } 40 \mathrm{mg} / \mathrm{kg}(\mathrm{T} 6.6 \mathrm{mg} / \mathrm{kg} / \mathrm{d} \\
+\mathrm{S} 33.3 \mathrm{mg} / \mathrm{kg} / \mathrm{d})+\mathrm{FA} \\
(15 \mathrm{mg} / \mathrm{d}) \\
\\
\mathrm{TS} 120 \mathrm{mg} / \mathrm{kg}(\mathrm{T} 20 \mathrm{mg} / \mathrm{kg}+\mathrm{S} \\
100 \mathrm{mg} / \mathrm{kg} / \mathrm{d})+\mathrm{FA}(15 \mathrm{mg} / \mathrm{d})\end{array}$ & $\begin{array}{l}\text { Skin and hematological changes } \\
\text { Skin changes }\end{array}$ \\
\hline 2. & $\begin{array}{l}\text { Cárrion et al. } \\
\text { (1999) }\end{array}$ & Cerebral & 1 & $\mathrm{P}(50 \mathrm{mg} / \mathrm{d})+\mathrm{S}(2 \mathrm{~g} \mathrm{3x} / \mathrm{d})$ & Stevens-Johnson syndrome \\
\hline 3. & $\begin{array}{l}\text { Caumes et al. } \\
(1995)\end{array}$ & Cerebral & $\begin{array}{l}18 \\
15\end{array}$ & $\begin{array}{c}\mathrm{P}(\mathrm{AD} 100 \mathrm{mg}+50 \mathrm{mg} / \mathrm{d})+\mathrm{S} \\
(4 \mathrm{~g} / \mathrm{d}) \\
\mathrm{P}(\mathrm{AD} 100 \mathrm{mg}+50 \mathrm{mg} / \mathrm{d})+\mathrm{C} \\
(2.4 \mathrm{~g} / \mathrm{d})\end{array}$ & $\begin{array}{c}\text { Skin changes / Stevens-Johnson and } \\
\text { Lyell syndromes } \\
\text { Skin changes }\end{array}$ \\
\hline 4. & $\begin{array}{l}\text { Marcos et al. } \\
\text { (1995) }\end{array}$ & Cerebral & 1 & $\begin{array}{c}P(75 \mathrm{mg} / \mathrm{d})+\mathrm{C}(600 \mathrm{mg} / 4 \mathrm{x} / \\
\mathrm{d})\end{array}$ & Skin changes \\
\hline 5. & $\begin{array}{l}\text { Iaccheri et al. } \\
\quad(2008)\end{array}$ & Ocular & $\begin{array}{c}2^{*} \\
3 \\
9 \\
13^{*} \\
4^{*}\end{array}$ & 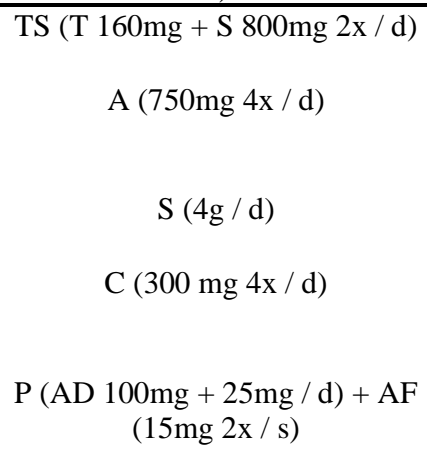 & $\begin{array}{c}2 \text { Skin changes and facial edema } \\
2 \text { Skin and } 1 \text { gastrointestinal } \\
\text { change } \\
\text { Skin changes } \\
6 \text { Skin and } 9 \text { gastrointestinal } \\
\text { changes } \\
1 \text { Hematological change, } 3 \\
\text { stomachage and } 1 \text { headache }\end{array}$ \\
\hline 6. & $\begin{array}{l}\text { Kim et al. } \\
(2002)\end{array}$ & Ocular & 1 & $\begin{array}{c}\text { TS (T 160mg / S 800mg / d) + C } \\
(600 \mathrm{mg} 4 \mathrm{x} / \mathrm{d})\end{array}$ & Skin and gastrointestinal changes \\
\hline 7. & $\begin{array}{l}\text { Helfenstein et } \\
\text { al. (2017) }\end{array}$ & Ocular & 9 & $\begin{array}{c}\mathrm{P}(\mathrm{AD} 75 \mathrm{mg} / 3 \mathrm{~d}+50 \mathrm{mg} / \mathrm{d})+ \\
\mathrm{S}(4 \mathrm{~g} / \mathrm{d})+\mathrm{FA}(15 \mathrm{mg} 2 \mathrm{x} / \mathrm{s})\end{array}$ & $\begin{array}{c}2 \text { Skin, } 2 \text { gastrointestinal and } 4 \\
\text { biochemical changes and } 1 \text { facial } \\
\text { edema }\end{array}$ \\
\hline 8. & $\begin{array}{l}\text { McLeod et al. } \\
\text { (2006) }\end{array}$ & Ocular & 1 & $\mathrm{P}+\mathrm{S}+\mathrm{FA}(\mathrm{DNR})$ & DRESS syndrome \\
\hline 9. & $\begin{array}{l}\text { Yusuf et al. } \\
\text { (2013) }\end{array}$ & Ocular & 1 & $\begin{array}{c}\mathrm{P}(50 \mathrm{mg} / \mathrm{d})+\mathrm{S}(1 \mathrm{~g} \mathrm{4x} / \mathrm{d})+ \\
\mathrm{FA}(15 \mathrm{mg} 2 \mathrm{x} / \mathrm{s})\end{array}$ & DRESS syndrome \\
\hline 10. & $\begin{array}{l}\text { Sousa et al. } \\
\text { (2016) }\end{array}$ & Ocular & 1 & $\begin{array}{c}\mathrm{P}(50 \mathrm{mg} / \mathrm{d})+\mathrm{S}(4 \mathrm{mg} / \mathrm{d})+\mathrm{FA} \\
(5 \mathrm{mg} / \mathrm{d}\end{array}$ & DRESS syndrome \\
\hline 11. & $\begin{array}{l}\text { Nucera et al. } \\
\quad(2000)\end{array}$ & Gestational & 1 & $\mathrm{TS}+\mathrm{E}(\mathrm{UD})$ & Skin changes \\
\hline 12. & $\begin{array}{l}\text { Ostlere et al. } \\
\text { (1991) }\end{array}$ & Gestational & 1 & $\mathrm{E}(1.5 \mathrm{~g} 2 \mathrm{x} / \mathrm{d})$ & Skin and hematological changes \\
\hline 13. & $\begin{array}{l}\text { Velter et al. } \\
\quad(2018)\end{array}$ & Gestational & 1 & $\mathrm{P}+\mathrm{S}$ (UD) & Stevens-Johnson syndrome \\
\hline 14. & $\begin{array}{l}\text { Teil et al. } \\
(2016)\end{array}$ & Congenital & 6 & $\begin{array}{l}\mathrm{P}(3 \mathrm{mg} / \mathrm{kg} \mathrm{3-3d})+\mathrm{S}(25 \mathrm{mg} / \\
\mathrm{kg} 4 \mathrm{x} / \mathrm{d})+\mathrm{FA}(50 \mathrm{mg} / \mathrm{s} 1 \mathrm{x} / \mathrm{s}) \\
\text { for } 2 \mathrm{~m} \text { and } \mathrm{P}(1.25 \mathrm{mg} / \mathrm{kg} 10- \\
10 \mathrm{~d})+\mathrm{SX}(25 \mathrm{mg} / \mathrm{kg} 10-10 \mathrm{~d}) \\
+\mathrm{FA}(50 \mathrm{mg} / \mathrm{s} 1 \mathrm{x} / \mathrm{s}) \text { for } 10 \mathrm{~m}\end{array}$ & Skin and hematological changes \\
\hline
\end{tabular}

Caption: P (oral Pyrimethamine), S (oral Sulfadiazine), FA (oral Folinic Acid), C (oral Clindamycin), TS (oral Trimethoprim and oral Sulfamethoxazole), E (oral Spiramicin), SX (oral Sulfadoxine), A (Atovaquone orally), d(Day), s (Week), $x$ (Times), $m$ (Months), AD (Attack dose), UD (Unreported dose).

* More than 1 adverse event was reported by the same patient.

'Biochemical changes: increased liver enzymes and creatinine

Source: Authors. 
Cutaneous AEs were reported in 13 studies (92.8\%), including skin changes, Lyell's syndrome (SL), and StevensJohnson syndrome (SJS). The most reported AE was skin changes (57.1\%), mainly associated with pyrimethamine treatment, with dosages in the range of $25-150 \mathrm{mg}$ per day. In addition, two studies reported adverse reactions in the gastrointestinal system, ${ }^{[6,7]}$ and in one of these, vomiting was the most prevalent reaction; ${ }^{[6]}$ however, diarrhea, stomach pain, and gastrointestinal bleeding were observed in another study. ${ }^{[7]}$ Three studies $(21.4 \%)$ reported the development of SJS ${ }^{[2,3,13]}$ using a combination of and sulfadiazine. In one study, eighteen patients $(18 / 85 ; 21.1 \%)$ manifested SL. ${ }^{[3]}$

Drug reaction with eosinophilia and systemic symptoms (DRESS) was reported in three studies $(21.4 \%)$, ${ }^{[8,9,10]}$ two of which also reported AEs such as liver failure, rash, hematological changes, and biochemical changes. ${ }^{\left[{ }^{8,10]}\right.}$ Furthermore, in one of the studies, ${ }^{[9]}$ rash, hematological changes, and persistent lymphadenopathy were reported. Despite the severe symptoms of DRESS syndrome (DS), all affected patients showed improvement in clinical signs after medication replacement and the administration of corticosteroids. The combination of pyrimethamine and sulfadiazine, at different dosages, together with folinic acid, was used to treat ocular toxoplasmosis. However, analysis of the studies concluded that the severe hypersensitivity reaction was due to sulfadiazine.

The profile of AEs associated with treatment using drugs differed according to the clinical manifestations of toxoplasmosis (Table 1). Spiramycin-based therapy was observed in $14.3 \%$ of studies on gestational toxoplasmosis with dermatological AEs. One of those 14 studies reported an AE in children with congenital toxoplasmosis, ${ }^{[14]}$ and six patients developed hematological changes such as neutropenia, eosinophilia, and anemia. These changes were considered to be consequences of treatment with a combination of sulfadoxine and pyrimethamine at doses of $3 \mathrm{mg} / \mathrm{kg}$ and $25 \mathrm{mg} / \mathrm{kg}$ per day, respectively. Similarly, Ben-Harari et al. (2017) reported AEs associated with bone marrow suppression in children with congenital infection using pyrimethamine and developed hematological modifications such as neutropenia, eosinophilia, thrombocytopenia, and anemia.

Two studies on cerebral toxoplasmosis, ${ }^{[3,4]}$ and two on ocular toxoplasmosis ${ }^{[5,6]}$ included trimetropime combined with sulfamethoxazole and clindamycin, as well as monotherapy with clindamycin and pyrimethamine, and clindamycin only, administered individually. In one of these studies on ocular toxoplasmosis, ${ }^{[6]}$ the therapy was based on trimetropime combined with sulfametoxazole and clindamycin, with a report of dermatological AEs caused by hypersensitivity to clindamycin treatment. This result corroborates other studies ${ }^{[3,4,5]}$ that also reported dermatological AEs due to the use of the trimetropime plus sulfametoxazole with clindamycin at daily dosages varying between $300 \mathrm{mg}$ and $2.4 \mathrm{mg}$.

The most frequent severe clinical manifestation of $T$. gondii is encephalitis (cerebral toxoplasmosis), which generally consists of several discrete brain lesions and is more common in immunosuppressed patients. In this study, 40 (47\%) of 85 patients with human immunodeficiency virus (HIV) infection developed cerebral toxoplasmosis. ${ }^{[1,2,3,4]}$ This analysis corroborates Vidal (2019), who reported that manifestations in the central nervous system (CNS) stand out among the severe clinical forms of toxoplasmosis, mainly affecting patients with acquired immunodeficiency syndrome (AIDS) due to the use of medications for the treatment of toxoplasmosis.

The combination of sulfadiazine and pyrimethamine is used in toxoplasmosis therapy, but it affects the CNS, as observed in two studies. ${ }^{[2,3]}$ However, due to adverse reactions, mainly caused by sulfadiazine, these drugs are typically replaced, or the treatment is abandoned. Marcos et al. (1995) highlighted that treatment of toxoplasmic encephalitis in HIVinfected patients occurs continuously throughout life. Thus, due to the remarkable occurrence of hypersensitivity reactions, the therapeutic arsenal has been shown to be insufficient for patients who continually need medications to combat $T$. gondii.

Thus, it was observed that the combination of pyrimethamine with sulfadiazine and folinic acid is the most used treatment regimen, despite the high risk of toxicity. According to Alday \& Doggett (2017), trials that used pyrimethamine with 
sulfadiazine for the treatment of toxoplasma encephalitis led to the discontinuation of therapy in one-third of patients. The study also highlighted that sulfadiazine can be replaced with clindamycin if the patient is allergic to drugs in the sulfonamides class of antibiotics. However, it has been observed that clindamycin is a less effective drug for preventing the recurrence of infection and that it also has similar toxicity rates.

Sulfonamides are often associated with rare and potentially fatal drug hypersensitivity reactions, such as DS. This reaction can cause rash, fever, lymphadenopathy, hematological changes, and affect internal organs (Yusuf et al., 2013; Karakayali et al., 2017). Furthermore, according to Cárrion-Cárrion et al. (1999), SSJ may also be reported after the administration of sulfonamides and is characterized by severe skin rashes (acute epidermal necrosis) and fatal syndrome in about $5 \%$ of cases. SL and SJS have different degrees of severity for the same conditions; however, SL is considered to be more severe (Siah et al., 2009).

Regarding the clinical manifestations of toxoplasmosis, it is important to emphasize that toxoplasmosis acquired during pregnancy is another means of transmitting the parasite and has significant relevance because of the risk of vertical transmission and the development of serious damage in the infected child, such as intracranial calcification, eye injury, and microcephaly or anencephaly. The most severe symptoms are observed in babies whose mothers were infected in the third trimester of pregnancy, in addition to abortion, which can also occur during this period (Esperança et al., 2019). Studies have reported that in the case of seropositivity, immediate treatment should be given using spiramycin. However, pyrimethamine, sulfadiazine, and folinic acid are administered in cases of suspected congenital infections. There are risks of adverse teratogenic and hematological effects, in addition to reactions that can also occur in the mother (Bernardo et al., 2015), as in Velter (2018), in which the development of SJS was verified in pregnant women after the administration of a combination of pyrimethamine and sulfadiazine.

Ocular toxoplasmosis also stands out as the most common cause of posterior uveitis, which mainly affects the retina and its underlying layer, causing focal necrotizing retinochoroiditis, which is characterized by pigmented macular lesions with necrotic spots on the retina (Lie et al., 2019). It appears that there are no antiparasitic agents capable of eradicating T. gondii from ocular tissues, and the most commonly used treatment, pyrimethamine plus sulfadiazine and folinic acid, still has questionable efficacy and can often cause more problems than the disease itself, such as provoking DRESS syndrome (Cárrion-Cárrion et al., 1999; Kim et al., 2002; Oliveira, 2012; Schallhorn \& Gonzales, 2013; Sousa et al., 2016; Velter et al., 2018).

In this review, the number of studies and the total sample size analyzed for each of the manifestations of toxoplasmosis were low. In addition, the specific dosage, study design, and patient population all differed between studies within a given clinical manifestation. Most treatment regimens involve combinations of drugs, which makes it difficult to analyze each drug's individual relationship to the reported AEs.

\section{Conclusion}

In this study, it was found that the profile of AEs associated with toxoplasmosis treatments differed according to the manifestation of toxoplasmosis, and the prevalence of AEs related to hematological changes was mainly in treatments based on pyrimethamine combined with sulfadiazine and trimethoprim combined with sulfamethoxazole. Dermatological changes associated with severe syndromes are often related to the use of pyrimethamine and sulfadiazine, both in ocular and brain toxoplasmosis, respectively. However, in gestational toxoplasmosis, this change is correlated with spiramycin-based therapy. Furthermore, in congenital toxoplasmosis, the most frequent AEs were associated with bone marrow suppression, with the use of pyrimethamine being linked to this change. Hence, the need for randomized clinical trials to compare the efficacy, profile of 
AEs, and medication adherence among the various medications used against toxoplasmosis is highlighted in order to establish a gold standard protocol. Considering this scenario, the development of safer, more efficient, and less toxic compounds against T. gondii is essential.

\section{Acknowledgments}

This study was financed in part by the Coordenação de Aperfeiçoamento de Pessoal de Nível Superior - Brasil (CAPES) -Finance Code 001

\section{References}

Alday, P., \& Dogget, J. (2017). Drugs in development for toxoplasmosis: advances, challenges, and current status. Drug Design, Development and Therapy, $11,273-279$.

Ben-Harari, R., Goodwin, E., \& Casoy, J. (2017). Adverse event profile of pyrimethamine-based therapy in toxoplasmosis: A systematic review. Drugs in $R \& D, 17,523-544$.

Bernardo, W., Chinzon, M., \& Chaves, F. (2015) Is sulfadiazine alone equivalent (benefit and harm) to spiramycin to treat acute toxoplasmosis in the first trimester of pregnancy? Revista da Associacao Medica Brasileira, 61, 495-496.

Canessa, A. et al. (1992) Cotrimoxazole therapy of Toxoplasma gondii encephalitis in AIDS patients. European Journal of Clinical Microbiology and Infectious Diseases, 11, 125-130.

Carrión-Carrión, C. et al. (1999) Fatal Stevens-Johnson syndrome in an AIDS patient treated with sulfadiazine. Annals of Pharmacotherapy, 33 , 379-380.

Caumes, E. et al. (1995) Adverse cutaneous reactions to pyrimethamine/sulfadiazine and pyrimethamine/clindamycin in patients with AIDS and toxoplasmic encephalitis. Clinical Infectious Diseases, 21, 656-658.

Deng, Y. et al. (2019) Recent progress on anti-Toxoplasma drugs discovery: design, synthesis and screening. European Journal of Medicinal Chemistry, 183, 111-711.

Dunay, R. et al. (2018) Treatment of toxoplasmosis: historical perspective, animal models, and current clinical practice. Clinical Microbiology Reviews, 31.

Franco, P. et al. (2019) Brazilian strains of Toxoplasma gondii are controlled by azithromycin and modulate cytokine production in human placental explants. Journal of Biomedical Science, 26, 1, 10.

Guaraldo, L. et al. (2018) Ocular toxoplasmosis: adverse reactions to treatment in a Brazilian cohort. Transactions of the Royal Society of Tropical Medicine and Hygiene, 112, (4)188-192, 2018.

Hedriana, H. et al. (1993) Normal fetal outcome in a pregnancy with central nervous system toxoplasmosis and human immunodeficiency virus infection. A case report. The Journal of Reproductive Medicine, 38, 747-750.

Helfenstein, M. et al. (2017) Ocular toxoplasmosis: therapy-related adverse drug reactions and their management. Klinische Monatsblatter Fur Augenheilkunde, 234, 556-560.

Iaccheri, B. et al. (2008) Adverse drug reactions to treatments for ocular toxoplasmosis: a retrospective chart review. Clinical Therapeutics, 30, $2069-2074$.

Karakayal1, B. et al. (2017) Drug Reaction with Eosinophilia and Systemic Symptoms (DRESS) syndrome associated with cefotaxime and clindamycin use in a 6 year-old boy: a case report. Pan African Medical Journal, 28, 218.

Kim, P., Younan, N., \& Coroneo, M. (2002) Hypersensitivity reaction to intravitreal clindamycin therapy. Clinical and Experimental Ophthalmology, 30, 147148.

Marcos, C. et al. (1995) Clindamycin desensitization in an AIDS patient. AIDS, 9, 1201-1202.

Mcleod, R. et al. (2006) Severe sulfadiazine hypersensitivity in a child with reactivated congenital toxoplasmic chorioretinitis. The Pediatric Infectious Disease Journal, 25, 270-272.

McKenzie JE. et al (2021). The PRISMA 2020 statement: an updated guideline for reporting systematic reviews. BMJ, 71, 372.

Nucera, E. et al. (2000) Tolerance induction to cotrimoxazole. Allergy, 55, 681-682.

Oliveira, C. (2012) Evaluation of anti-toxoplasmic, antioxidant and anti-inflammatory activities of Thymol (Lippia sidoides) and Estragole (Croton zenhtneri) [Dissertation]. Federal University of Rio Grande do Norte.

Ostlere, L., Langtry, J., \& Staughton, R. (1991) Allergy to spiramycin during prophylactic treatment of fetal toxoplasmosis. BMJ, $302,970$.

Paradynski, G. et al. (2019) Health care actions through biomedical professionals in the diagnosis and prevention of Toxoplasmosis. Revista Integrada Saúde, $12,140-152$. 
Research, Society and Development, v. 10, n. 13 e505101321339, 2021

(CC BY 4.0) | ISSN 2525-3409 | DOI: http://dx.doi.org/10.33448/rsd-v10i13.21339

Schallhorn, J., \& Gonzales, J. (2013) Ocular toxoplasmosis: the treatment dilemma. Journal of AAPOS \{JAAPOS\}, 17, 454-455.

Serrano, M. et al. (2016) Toxoplasmosis in pregnancy: bibliographic review. Connection line - electronic. Journal of Univag, 14.

Siah, S. et al. (2009) Treatment of Lyell's syndrome or toxic epidermal necrolysis. Annals of Burns and Fire Disasters, 22, $142-146$.

Sousa, J. et al. (2016) DRESS syndrome in ophthalmic patients. Arquivos Brasileiros de Oftalmologia, 79, $192-194$.

Teil, J. et al. (2016) Treatment of congenital toxoplasmosis: safety of the sulfadoxine-pyrimethamine combination in children based on a method of causality assessment. Pediatric Infectious Disease Journal, 35, 634-638.

Velter, C. et al. (2018) Stevens-Johnson syndrome during pregnancy: case report of a newborn treated with the culprit drug. JAMA Dermatology, 154, 224225 .

Vidal, J. (2019) HIV-Related Cerebral Toxoplasmosis Revisited: Current Concepts and Controversies of an Old Disease.J Int Assoc Provided AIDS Care, 18, $1-20$.

Wei, H. et al. (2015) A systematic review and meta-analysis of the efficacy of anti-Toxoplasma gondii medicines in humans. PLOS ONE, 10, $138-204$.

Yusuf, I. et al. (2013) DRESS syndrome in a child treated for toxoplasma retinochoroiditis. Journal of AAPOS, 17, $521-523$. 